\title{
EFL Students' Perceptions of Teacher Feedback and Intra-Feedback in Writing Essays
}

\author{
Maryam Kazemi \\ University of Mazandaran, Iran \\ Shirin Abadikhah* \\ University of Mazandaran, Iran \\ Mahmood Dehqan \\ University of Mazandaran, Iran
}

\section{Introduction}

Feedback has long been a central aspect of L2 writing programs, both for its potential for learning and for student motivation (Hyland \& Hyland, 2006). Arndt (1993) believes that "feedback informs the writing process, permeating, shaping, and moulding it" and considers it as a "central and critical contribution to the evolution of a piece of writing" (cited in Tsui \& $\mathrm{Ng}, 2000$, p. 148). Two major feedback delivery methods, commonly used in EFL classrooms, are teacher written feedback and peer feedback. Considering the dynamics and constraints involved in teacher written feedback as well as L2 students' reactions and expectations and needs, Goldstein (2004) has argued that teachers' feedback practices are influenced by "multiple contextual, teacher and student factors interacting and mediating each other" (p. 67). Rollinson (2004) found that Korean students receiving feedback from their teachers felt that their teachers are the only audience of their writing. Hence, L2 researchers have suggested that teachers change their responding behavior in order to enhance the effectiveness of their comments and the quality of students' revisions (Goldstein, 2004). They have also advised L2 instructors to construct an interpersonal relationship with students through written commentary in order to provide them with useful and appropriate intervention to avoid appropriation and misinterpretation (Goldstein, 2004). Finally, L2 writing teachers have been recommended not only to discuss their commentary philosophy, the rationale behind their feedback practices, and the way their comments should be

\footnotetext{
${ }^{1}$ Corresponding author
} 
interpreted and enacted with the students, but also to consider students' preferences and expectations (Ferris, 2003; Goldstein, 2004).

Peer feedback has been defined as "the use of learners as sources of information, and interactants for each other in such a way that learners assume roles and responsibilities normally taken on by a formally trained teacher, tutor or editor in commenting on and critiquing each other's drafts in both written and oral formats in the process of writing" (Liu \& Hansen, 2002, p. 1). Peer-peer feedback has been implemented under various forms including peer review, peer response, peer evaluation or assessment and peer editing. As Bitchner and Ferris (2012) have stated, "peer review activities can be used to help students apply and practice specific self-editing strategies they have been taught" and can "build student confidence in self-editing skills" (p.155). The learning benefits of peer feedback is mutual since not only the student writers but also the student reviewers or editors can improve their writing skills by means of observing their classmates' approaches to writing, and internalizing writing criteria and standards (Abadikhah \& Yasami, 2014).

The theoretical underpinning of peer feedback is based on the sociocultural theory of mind (Vygotsky, 1978), underlining the fact that peer interaction incorporates both the cognitive and social aspects of language by allowing peers to make meaning within the framework of dialogic interaction (Zhang, 1995); consequently, it suggests an ideal basis for the study of peer feedback. Adopting this theoretical perspective, second language acquisition (SLA) scholars have assumed writing as a skill which is in the social context, rejecting the outdated view that considers writing as an individual act in which the author wants to convey his/her meaning to the intended audience (Santos, 1992, p. 3). On the other hand, feedback practices in writing classrooms, whether between students and teachers or between peers, can be considered as a tool by which writing skill is developed and internalized. Its absence in composition classes regards writing as an individual engagement in which learners attempt to express their messages without having an opportunity to discuss them with their audience and taking advantage of sharing and pooling expertise.

Students' perception of these two sources of feedback has been the subject of numerous studies (Jacobs, Curtis, Braine, \& Huang, 1998; Zhang, 1999). According to Bitchener and Ferris (2012), "student writers have strong beliefs about their need for expert corrective feedback, and if the job is turned over to their peers in the classroom, they may feel anxious about not receiving adequate or accurate input" (p.154). The study by Zhang (1995), for instance, which was conducted on ESL learners at two different universities in the U.S. confirms this 
claim. The results of this study indicated that $94 \%$ of learners preferred teacher feedback to peer feedback. On the other hand, Jacobs et al. (1998), who examined EFL students' attitudes towards teacher and peer feedback, found that $93 \%$ of their learners preferred to receive peer feedback. Similarly, Tsui and Ng's (2000) study of Hong Kong secondary school students and Hu's (2005) study of Chinese students studying English in Singapore, indicated their students' preference for peer feedback.

Some studies also indicated that different groups of learners deal with peer feedback differently. According to Allaei and Connor (1990), students' culture had a significant effect on the efficiency of peer feedback groups. For instance, Nelson and Murphy (1993) discovered that Chinese speaking students disliked to accept the right of non-native speakers of English to judge their writing papers. Likewise, Nelson and Carson (1998) concluded that ESL students from countries with a large power distance were less likely to welcome their peers' views than were students from countries with a lower power distance. In addition to culture, the effect of some other factors on learners' perception of feedback provider were investigated. In another study, Azarnoosh (2013) investigated friendship bias in giving peer feedback and the effect of this practice on the learners' perceptions. According to the results, no friendship bias was found in peer feedback and this practice positively influenced the students' attitudes towards peer feedback.

Thus, the literature indicates substantial variability in the learners' preferences for feedback provider and perceptions of their effectiveness. Moreover, the majority of the research has focused on the learners' perception of the feedback provider considering some cultural and biological factors while the reviewing process was not taken into account. In a recent study, Lee (2015) considered this factor and introduced a novel approach in reviewer-oriented practice, namely, intra-feedback. Intra-feedback is defined as "a peer-feedback-on-peer-feedback task directed by and targeted at individual reviewers" (p. 3). He examined junior secondary L2 students' perceptions of peer feedback, and found that the options of having teacher feedback and a combined mode were significantly preferable to the option of having peer feedback provided by one peer. This study intends to extend the scope of this line of research by investigating the perceptions of EFL students towards teacher feedback and joint peer reviewer oriented feedback by implementing intra-feedback practice. 


\section{Literature Review}

Several different studies have elicited L2 learners' perceptions of and attitudes towards teacher and peer feedback by focusing on their views about the efficiency and value of teacher and peer feedback and their relative appeal. For instance, Keh (1990) examined Cantonese students' perceptions of peer feedback and claimed that learners benefited from peer feedback. The participants expressed that since their papers were reviewed by readers other than their teachers, peer feedback assisted them to obtain a greater sense of audience. Moreover, according to the results, peer feedback was regarded useful because of receiving immediate, live feedback and developing learners' critical thinking and "analytical power" (p. 269).

In order to examine the learners' concerns and expectations about error correction, Leki (1991) surveyed 100 college-level ESL composition learners. According to the findings, the majority of the respondents (91\%) perceived accuracy in writing as a crucial element. Furthermore, more than two-third of the learners preferred their teachers' reference to both their major and minor errors and $67 \%$ wished their teachers not only to determine their errors but also to write a clue about their accurate forms. The participants judged their teachers as the most helpful source of feedback and peer feedback was reported to be the least beneficial. Leki concluded that ESL students are greatly in favor of developing error-free writings and suggested that teachers might devote the time of class to discuss with their learners the methodologies they prefer.

Mangelsdorf (1992) conducted a study with 40 heterogeneous advanced ESL learners at the University of Arizona. She aimed at addressing some of the reservations which were stated concerning the use of peer feedback in composition. Her data were composed of students' written answers to the four questions eliciting their opinions about usefulness of peer evaluation, the focus of peer comments, students' feedback preferences, and the value of peer-review process (pp. 275276). She also wanted instructors to write down their reflections on advantages and disadvantages of peer feedback technique. Both students and teachers confirmed that peer feedback could help student writers to comprehend their audience expectations, to view their texts from their viewpoints and to clarify the misinterpretations if needed. Based on the findings, Mangelsdorf recommended some techniques for improvement of peer review efficiency including modeling the peer feedback, briefing learners about the goal of the activity, making students to review an essay jointly, conferencing with students and helping them in the revisions, carefully structuring the groups, and allocating a percentage of the course grade on peer review practices. She concluded that "peer review takes 
patience - from both students and teachers", if it is carefully structured, it is valuable and can be efficient (p. 283).

Hyde (1993) criticized teachers' use of pair work without considering students' preferences and being clear on pair selection criteria. Therefore, he elicited $20 \mathrm{EFL}$ students' attitudes towards pair work using questionnaire and interviews. According to the results, the learners were not concerned about gender and age difference but were concerned about their pair's personalities and characteristics. The participants also preferred working with different partners during the semester so that they could gain a wide range of ideas. The most favorable type of interaction was teacher-centered form in which the whole class interacted with the teacher; in addition, the least preferred one was pair work. In short, Hyde did not reject the use of pair work in classrooms but suggested group work as a better alternative technique because it would give students a wider choice.

Carson and Nelson (1996) examined the negotiation and reflections of three advanced Chinese ESL university students concerning peer response groups. The interactions of learners were videotaped and their reactions to the activities were stimulated by the use of retrospective interviews. Moreover, the research included two Spanish-speaking learners for the purpose of comparison and triangulation of data. Data analysis revealed useful information about the participants' perceptions of peer response group interactions. Specifically, the researchers found that Chinese students did not criticize their peers' papers since they were concerned not to hurt the writers' feelings. Hence, they refused to discuss with their peers as they thought it would damage group relations. Their limited language proficiency and their incapability to offer valid alternatives was another reason for not providing honest peer feedback. Finally, the findings of their study revealed that the students' "primary goal was to maintain group harmony, and this goal affected the nature and types of interaction they allowed themselves in group discussions" (p. 7). They emphasized that this view was in contrast with "highly individualistic cultures" in which "writing group functions more often for the benefit of the individual writer than for the benefit of the group" (p. 2).

Zhang (1995) investigated 81 tertiary level ESL students in a questionnaire-based study. Although all of the participants had adequate exposure to teacher, peer, selffeedback, the length of residence of them in an English-speaking country differed. In fact, Zhang's main concern was to verify whether the affective benefits of peer feedback in L1 context was appropriate for ESL instruction. Doing some statistical analyses, he reported that the majority of respondents (93.8\%) indicated a very strong desire for teacher feedback. However, the students claimed that peer feedback was preferable (60.5\%) to self-feedback. Finally, he suggested ESL 
investigators to critically re-consider and make necessary changes to "L1-based theoretical stances or pedagogical emphases" (p. 218) before generalizing them to ESL context.

Jacobs and his colleagues (1998) surveyed 121 ESL undergraduate university students' reactions to peer feedback and offered some suggestions for successful implementation of this activity in L2 writing classes. The study was carried out in Taiwan and Hong Kong and the participants' proficiency levels ranged from lower to upper intermediate. Indeed, their purpose was to question Zhang's (1995) method of discovering ESL students' feedback preferences on a dichotomous basis (i.e., choosing either teacher or peer). Hence, they altered the question and asked the learners whether they liked their papers be reviewed by their classmates or not. The respondents, therefore, were not obliged to select between teacher and peer feedback but rather to focus only on whether they liked or disliked peer feedback. From the statistical analysis of the data, it was found that a great majority of the learners $(93 \%)$ welcomed receiving feedback from their peers on their writings. The two most common responses which were found in the participants' answers were that "peers provided more ideas and were able to spot problems they had missed" (p. 312). As a result, the researchers recommended a "middle path" which was a "judicious use of a combination of feedback sources; teacher, peer, and selfdirected feedback" (p. 314).

Nelson and Carson (1998) inspected 11 advanced ESL students' perceptions of peer feedback effectiveness at a large metropolitan university in the U.S. Data collection tools included videotaping of all peer response group sessions, which was followed by interviewing 5 participants. Using stimulated recall, they tried to elicit interviewees' responses to the discussions they had. Qualitative analysis of data indicated that all of the participants valued constructive feedback since it improved revisions. In addition, the learners were more in favor of teacher feedback rather than peer feedback. However, Chinese students' perception of the key role of peer feedback differed from their Spanish classmates; while they referred to group work as the main objective of peer feedback, Spanish students' central focus was on the task and refining the papers of the group members. The researchers concluded that the use of peer feedback practices in ESL composition classes should be re-examined since L2 students are still in the process of learning second language and are not confident enough in their abilities.

In order to elicit business students' perceptions of peer collaboration and assessment, Roskams (1999) carried out a broad survey study at the Chinese university of Hong Kong. The participants $(n=217)$ who had pair works both in and out of class in order to communicate and practice writing skills, were surveyed 
once before and then after experiencing collaborative learning. According to the analysis, the participants (a) showed stronger collectivist motivation than achievement motivation, (b) had more positive reactions to joint work rather than individual work, (c) were more interested in teacher comments, although found partner feedback helpful, (d) did not accept that collaboration made them work harder than they worked alone, (e) expressed that pair work was enjoyable and beneficial since it helped them make new relationships, share the workload of the tasks, widen their horizon, and gain better grades, and (f) considered peer feedback and giving feedback more beneficial than being evaluated and receiving feedback. But, they indicated doubts about the quality of peer feedback practices. The researcher concluded that assigning students into pairs or groups and merely asking them to work jointly does not necessarily lead to successful collaborative learning context since teachers are required to "train students explicitly in collaborative skills, ensure individual accountability, monitor the groups and inculcate a theme of cooperation" (p. 103).

Tsui and Ng (2000) examined feedback incorporation behaviors of 27 Chinese preuniversity L2 writers in Hong Kong. They used a questionnaire, students' original and revised drafts, and follow-up interviews in order to compare the relative effectiveness of teacher and peer comments in facilitating revision. The responses of the participants to the questionnaire revealed their more positive attitudes towards teacher feedback than peer feedback and they preferred reviewing their classmates' writing significantly more than reading their comments or listening to their oral feedback. Moreover, participants implemented teacher suggestions in their revised drafts more frequently than peer feedback. The findings of the survey were consistent with those obtained from the interview data in which the perceptions were elaborated. The reason for students' more positive attitude towards teacher feedback was his ability in giving more specific, better quality, and concrete feedback. Moreover, the participants did not incorporate peer feedback since they did not trust in peers' feedback. However, students assigned four advantages to peer feedback (a) it raised their sense of audience, (b) boosted their self- monitoring skill, (c) improved collaborative learning, and (d) helped the ownership of the text (pp. 166-167). At the end, they suggested that oral discussion of the comments is necessary for learners since the use of only written comments may not be adequate.

To understand peer feedback characteristics as well as student reactions to this practice, Saito and Fujita (2004) carried out a comparative study on 61 Japanese business management students at a university in Tokyo. Indeed, the purpose of the research was to find out the similarities or differences among self-, peer, and teacher ratings of papers and factors which influence student attitudes in EFL 
writing classes. Using a simplified essay evaluation model, created by Jacobs et al. (1981), the learners assessed both their peers and their own essays. Based on the analysis, significant similarities were observed between the peers' and instructors' scoring methods. Moreover, learners indicated positive attitudes towards peer evaluation irrespective of the score they had received from their peers. Hence, the researchers concluded that their findings contradicted the negative beliefs articulated by experts regarding the invalidity of peer feedback and supported students' capability in giving qualified feedback in EFL writing classes.

Morra and Romano (2009) conducted a study with 108 EFL undergraduate students and interviewed two teachers at the School of Languages, National University of Córdoba, Argentina. The purpose of this study was to discover the reactions of EFL undergraduate students to peer feedback. Because of dissatisfaction of EFL teachers and reluctance of EFL students with the current peer feedback approach employed in EAP writing classes, the researchers of this study aimed to solve the problem and improve the instructional approaches of EAP writing courses. Drawing on the results of the study, they concluded that providing appropriate training with establishing friendly and stress-free atmosphere among peer feedback group members and restricting learners' focus to revision may result in successful peer feedback sessions.

Kaufman and Schunn (2011) explored the origin of students' resistance to peer evaluation in writing and its relationship to their revision writing. A questionnaire gathered responses of 250 undergraduate students in ten disciplines across six universities and also a follow-up interview with 84 participants was carried out. The findings showed that the participants articulated the most negative opinions about peer feedback as it was unfair and unreliable since the only source of grading was peers. Furthermore, after participating in peer feedback sessions, the doubts of participants about the quality of the peer feedback increased sharply. Furthermore, the findings also showed that the students paralleled fairness of peer feedback with the content and usefulness of the feedback they received and their attitudes towards peer feedback did not affect their revision. The researchers suggested that instructors could lessen students' anxieties about the fairness of peer feedback by engaging in the grading process and providing them with training and support for conducting peer feedback.

Kahraman and Yalvaç (2015) investigated 93 EFL Turkish university learners' attitudes towards teacher feedback and the effect of gender on their preferences. At the first stage of data collection procedure, the participants were given two short paragraphs and were asked to find their grammatical errors. At the second stage, the participants wrote a short paragraph about their favorite town or city. Finally, 
two copies of the students' writing were given to the teacher for feedback provision. After these three stages, a questionnaire which was divided into two parts was administered to the participants. Then, an interview was conducted with 14 volunteer students to find out their attitudes toward and preferences for teacher's feedback. The result showed that most of these learners had positive attitudes toward teacher feedback. Moreover, gender did not have any significant effect on the learners' attitudes.

In a recent study, Lee (2015) conducted a comparative research investigating junior secondary L2 students' perspectives on peer feedback. He compared the students' perceived usefulness of peer and teacher feedback and examined their preferences for different feedback modes. For data collection, a questionnaire and an interview were employed. The results indicated that the participants showed a statistically significant preference for inclusion of intra-feedback in peer feedback practice, and both the options of having teacher feedback only and a combined mode were significantly preferable to the option of having peer feedback alone.

In line with the above arguments, the purpose of the present study is to investigate EFL university students' preference for peer feedback and teacher feedback by employing the recently-developed practice of intra-feedback and by examining its value with reference to the student perceptions. Considering the emphasis placed on the oral discussion of the comments for learners and inadequacy of one peer's written comments, the intra-feedback practice may bring about promising outcome. Furthermore, different stages of peer feedback including reading and commenting on peers' essays, discussing one's own comments on peers' essays with a partner, reading peer comments on one's own essays, and discussing peer comments in an oral response session will be examined. To this end, the following research questions are addressed:

1) How do EFL students assess different stages of intra-feedback and teacher feedback in terms of their usefulness for their writing improvement?

2) What are EFL students' perceptions of feedback provider, feedback focus, feedback provision and intra-feedback inclusion?

\section{Method}

\section{1. Participants}

The present study involved a common sampling technique, namely, convenient sampling (Dorniye, 2003), allowing the researchers for data collection from an 
intact class. The participants were 21 year-four university students within the age range of 20-22. They were studying English literature at a state university in Mazandaran province, Iran. All of them were native speakers of Persian and had no experience of living in a foreign country. In the first meeting, the participants were provided with detailed information about the stages and procedure of the study. All participants expressed their satisfaction to participate in the consent forms. In order to provide teacher feedback, an EFL teacher, holding MA in TEFL, participated in this study. He had five years of teaching experience at different institutes from beginner to advanced levels and was quite familiar with the practice of feedback provision.

\subsection{Instruments}

The study involved a mixed method design. More precisely, the quantitative data were obtained from the questionnaire employed to explore the participants' reactions to the comments they received from their peers and teacher and also their perceptions of the extent to which the teacher and peer's comments improved the quality of their essays. In addition, qualitative data were obtained using semistructured interviews focused on questions related to teacher comments and peer comments. The diversity of the collected data could ensure triangulation which entails "inspection of different kinds of data, different methods, and a variety of research tools" in a single investigation (van Lier, 1988, cited in McGroarty \& Zhu, 1997, p. 3).

\subsubsection{Questionnaire}

A questionnaire adapted from Lee (2015) was administered to the participants. The final questionnaire, after being piloted and revised contained four constructs representing different stages of peer- and teacher feedback. The different stages of peer feedback included reading and commenting on peers' essays (construct 1), discussing one's own comments on peers' essays with a partner (construct 2) and reading peer comments on one's own essay (construct 3). The last construct (4) was about reading teacher's comment. Each item consisted of a 5-point scale with responses ranging from 'strongly agree' to 'strongly disagree'.

\subsubsection{Semi-structured interview}

In order to illustrate the findings, quantitative data were integrated with the qualitative data obtained from open-ended questions of semi-structured interviews with the participants. The rationale behind the open-ended questions was to generate relevant data to support the quantitative data. Dörnyei and Taguchi (2010) point out that the inclusion of open-ended questions results in greater richness of 
the responses and helps to identify previously unanticipated issues. The interview questions adapted from Tsui and $\mathrm{Ng}(2000$, p.157) asked about their preferences toward feedback provider (teacher/peer), feedback focus, feedback provision (usefulness of giving comments) and intra-feedback inclusion (usefulness of intrafeedback implementation in their class).

\subsection{Procedures}

The class met weekly for 40 minutes for the duration of 4 weeks. The students wrote essays on three topics in three different writing cycles. For each cycle, one topic was selected. They wrote argumentative essays on topics selected from IELTS preparation textbooks. The topics chosen from these books were first piloted with a similar sample and proved to be appropriate for the level of participants of this study. The participants were randomly assigned into seven triads. In each cycle, one of the students was the writer and the other two were reviewers.

In the first three weeks, the same process of writing and reviewing was followed. More specifically, in the first session, the student writers wrote about a specific topic in 40 minutes. After the first session, one of the researchers made two copies of the written drafts to be delivered to the peer members of the triad (reviewers) and the teacher. In the second session, firstly the two peer reviewers of each triad wrote separate comments on the written drafts within their group. Next, they discussed their comments to reach a joint comment in an intra-feedback process. Finally, the joint comment of the reviewers and the teacher's comment were given to the writer in order to write two separate revisions. This process lasted for three weeks so that all the three members of each triad experienced being both writers and reviewers. In week four, the questionnaire and interview were administered and the necessary data were collected.

\section{Result}

The purpose of the current study was to investigate the participants' perceptions of peer and teacher feedback. Firstly, the findings of the questionnaire, related to different stages of peer feedback, are presented in the form of descriptive statistics (Tables 1-6). Secondly, the findings of the interview are reported (Tables 7-11).

The first research question asked: "How do EFL students assess different stages of intra-feedback and teacher feedback in terms of their usefulness for their writing improvement?". Table 1 summarizes the ranking of the means of students' 
responses to different items of the first construct of the questionnaire, which considers the participants' perspective as reviewers of their peers' essays.

Table1. Students' perceptions about reading and commenting on their classmates' compositions

\begin{tabular}{|l|c|c|}
\hline \multicolumn{1}{|c|}{$\begin{array}{l}\text { Questionnaire Items: Construct one } \\
\text { Number of respondents=21 }\end{array}$} & M & SD \\
\hline $\begin{array}{l}\text { Item 1 I found reading and commenting on my classmates' compositions } \\
\text { useful. }\end{array}$ & 4.19 & .679 \\
\hline $\begin{array}{l}\text { Item 4 Reading and commenting on my classmates' compositions helped } \\
\text { me improve the language (including grammar and vocabulary) of my } \\
\text { composition. } \\
\text { Item 5 I benefited from reading and commenting on my classmates' } \\
\text { compositions. } \\
\text { Item 2 Reading and commenting on my classmates' compositions helped } \\
\text { me enrich the content of my composition. }\end{array}$ & 4.14 & .853 \\
\hline $\begin{array}{l}\text { Item 3 Reading and commenting on my classmates' compositions helped } \\
\text { me improve the organization of my composition. }\end{array}$ & 3.85 & .804 \\
\hline \begin{tabular}{l} 
Total mean \\
\hline
\end{tabular} & 4.03 & .758 \\
\hline
\end{tabular}

As the table shows, the students enjoyed the experience of commenting on their peers' written drafts. The comments were favorably viewed as the means of items related to construct one for students ranged from 4.19 to 3.85. Item 3 took up the lowest position and item 1 took up the top position in the table. As the table shows, the students were positive about reading and commenting on their classmate's compositions (total mean $=4.03$ ) and found the act of commenting useful for improvement of language, content and organization, respectively.

Table 2 summarizes the ranking of the means of students' responses to different items of the second construct of the questionnaire, focusing on the intra-feedback technique. 


\section{Table 2. Students' perceptions of discussing their comments on their classmates' compositions with a partner}

\begin{tabular}{|c|c|c|}
\hline $\begin{array}{c}\text { Questionnaire Items: Construct two } \\
\text { Number of respondents }=21\end{array}$ & $\mathbf{M}$ & SD \\
\hline $\begin{array}{l}\text { Item } 10 \text { I benefited from discussing my comments on my classmates' } \\
\text { compositions with a partner. }\end{array}$ & 4.33 & .795 \\
\hline Item 6 I found discussing my comments on my classmates' compositions & 4.19 & .749 \\
\hline Item 8 Discussing my comments on my classmates' compositions with a & 4.00 & .836 \\
\hline $\begin{array}{l}\text { Item } 9 \text { Discussing my comments on my classmates' compositions with a } \\
\text { partner helped me improve the language (including grammar and } \\
\text { vocabulary) of my composition. }\end{array}$ & 4.00 & .836 \\
\hline $\begin{array}{l}\text { Item } 7 \text { Discussing my comments on my classmates' compositions with a } \\
\text { partner helped me enrich the content of my composition. }\end{array}$ & 3.95 & .864 \\
\hline Total mean & 4.09 & .816 \\
\hline
\end{tabular}

The table shows that the students benefited from discussing their comments on their classmates' compositions with a partner. The comments were favorably viewed as the means of items related to construct two (about reading and commenting on my classmates' compositions) for students ranged from 4.19 to 3.85. While item 7 took up the lowest position and item 10 took up the top position in the table. As the table shows, the students were positive about intra-feedback technique (total mean= 4.09), and found the act of discussing their comments with another peer reviewer useful for improvement of organization, language and content, respectively. The total mean score for construct two (intra-feedback) (4.09) was slightly higher than that for the construct one (4.03).

Table 3 summarizes the ranking of the means of students' responses to different items of the third construct of the questionnaire, which was about reading peer comments on their composition. 
Table 3. Students' views about reading peer comments on their composition

\begin{tabular}{|l|c|c|}
\hline \multicolumn{1}{|c|}{$\begin{array}{c}\text { Questionnaire Items: Construct three } \\
\text { Number of respondents=21 }\end{array}$} & M & SD \\
\hline Item 11 I found my classmates' written comments useful. & 4.28 & .783 \\
\hline Item 15 I benefited from my classmates' written comments. & 4.28 & .717 \\
\hline $\begin{array}{l}\text { Item 14 My classmates' written comments helped me improve the } \\
\text { language (including grammar and vocabulary) of my composition. }\end{array}$ & 4.14 & .853 \\
\hline $\begin{array}{l}\text { Item 13 My classmates' written comments helped me improve the } \\
\text { organization of my composition. }\end{array}$ & 3.90 & .768 \\
\hline $\begin{array}{l}\text { Item 12 My classmates' written comments helped me enrich the } \\
\text { content of my composition. }\end{array}$ & 3.90 & .830 \\
\hline Total mean & 4.10 & .790 \\
\hline
\end{tabular}

Table 3 indicates that the students appreciated reading peer comments on their composition. The comments were favorably viewed as the means of items related to this construct ranged from 4.28 to 3.90. Item 11 took up the lowest position and item 12 secured the top position in the table. As the table shows, the students found classmates' written comments useful (total mean=4.10), as they perceived the act of reading peer comments useful for improvement of language, organization and content, respectively.

Table 4 shows the ranking of the means of students' responses to different items of the fourth construct of the questionnaire, which focused on reading the teacher's comments.

Table 4. Students' perceptions about reading teacher's comments

\begin{tabular}{|l|c|c|}
\hline \multicolumn{1}{|c|}{$\begin{array}{l}\text { Questionnaire Items: Construct four } \\
\text { Number of respondents=21 }\end{array}$} & M & \\
\hline $\begin{array}{l}\text { Item 16 I found reading my teacher's comments useful. } \\
\text { Item 17 My teacher's comments helped me enrich the content of } \\
\text { my composition. }\end{array}$ & 4.33 & .597 \\
Item 20 I benefited from reading my teacher's comments. & 4.28 & .717 \\
$\begin{array}{l}\text { Item 18 My teacher's comments helped me improve the } \\
\text { organization of my composition. }\end{array}$ & 4.09 & .768 \\
$\begin{array}{l}\text { Item 19 My teacher's comments helped me improve the language } \\
\text { (including grammar and vocabulary) of my composition. }\end{array}$ & 4.00 & .774 \\
\hline Total mean & 4.22 & .702 \\
\hline
\end{tabular}


According to Table 4, the students liked reading the teacher's comments. The comments were favorably viewed as the means of items ranged from 4.42 to 4.00 . Item 16 took up the lowest position and item 19 took up the top position in the table. Generally, the students found reading teacher's comments useful (total mean=4.22). The students found the act of reading teacher's comments useful for improvement of content, organization and language, respectively.

Table 5 presents the ranking of the average of the means of students' responses to the four constructs of the questionnaire. The result of this comparison indicates that construct 4 achieved the highest mean rank among the four constructs, suggesting that the respondents found reading teacher's comments on their composition more favorable than other forms of feedback.

\section{Table 5. Mean rank of the four constructs}

\begin{tabular}{|l|c|c|}
\hline \multicolumn{1}{|c|}{ Number of respondents=21 } & M & SD \\
\hline Construct 4: Reading teacher's comments on their composition & 4.22 & .702 \\
Construct 3: Reading peer comments on their composition & 4.10 & .790 \\
$\begin{array}{l}\text { Construct 2: Discussing their comments on their classmates' } \\
\text { compositions with a partner }\end{array}$ & 4.09 & .816 \\
$\begin{array}{l}\text { Construct 1: Reading and commenting on my classmates' } \\
\text { compositions }\end{array}$ & 4.03 & .758 \\
\hline
\end{tabular}

Since construct 3 (Reading peer comments on my composition) and construct 4 (Reading teacher's comments) represents students perceptions towards teacher and peer feedback, all students responses on the 5- point scale on these two constructs were compared using a chi square test.

Table 6. Chi-Square Test on the students' responses to the constructs 3 and 4

\begin{tabular}{|l|l|l|l|}
\hline & \multicolumn{1}{|c|}{ Valid } & \multicolumn{1}{c|}{ df } & \multicolumn{1}{|c|}{ Asymp. Sig. (2-sided) } \\
\hline Pearson Chi-Square & 39.900 & 12 & .000 \\
\hline Likelihood Ratio & 24.228 & 12 & .018 \\
\hline Linear-by linear Association & 5.690 & 1 & .017 \\
\hline N of Valid Cases & 21 & & \\
\hline
\end{tabular}

As it is demonstrated on Table 6, the difference between these two constructs is highly significant $(\mathrm{p}=.000)$, suggesting that the students significantly perceived the teacher's comments more useful than the comments they received from their peers. 
The second research question addressed the participants' perceptions of feedback provider, feedback focus, feedback provision and intra-feedback inclusion in EFL writing class. All the students took part in the interview on the last session. The students' responses are described and examined one by one in the following tables. They are categorized according to the main theme of the students' answers (to keep the anonymity, the names of the interviewees are fake names below). Table 7 summarizes the excerpts of the students' responses to the first question of interview ("What types of peer comments do you prefer?").

\section{Table 7 Selected Interview Excerpts of Q1}

\begin{tabular}{|c|c|c|}
\hline Student & Interview excerpts & Main theme \\
\hline Sana & $\begin{array}{l}\text { I think most of our readers are proficient enough to recognize } \\
\text { our linguistic errors because the rules are obvious. But the } \\
\text { thing without which our writing will not be clear is } \\
\text { organization. }\end{array}$ & Only organization \\
\hline Hasan & $\begin{array}{l}\text { In my opinion the organization is very important. A good } \\
\text { organization converys our message even if we have } \\
\text { grammatical mistakes. }\end{array}$ & Only organization \\
\hline Rima & $\begin{array}{l}\text { As I usually have very few grammatical and punctuation } \\
\text { mistakes, I appreciate comments that refer to these mistakes. }\end{array}$ & Only organization \\
\hline Elyar & $\begin{array}{l}\text { I like to receive comments on language and mechanics; } \\
\text { moreover, I know that comments about content and } \\
\text { organization are important. Because the reviewer/reader can } \\
\text { comprehend the message which is written in a well organized } \\
\text { manner. }\end{array}$ & $\begin{array}{l}\text { Both organization } \\
\text { and language }\end{array}$ \\
\hline Azin & $\begin{array}{l}\text { I think both organizational and linguistic comments are } \\
\text { necessary for improvement of our writing. }\end{array}$ & $\begin{array}{l}\text { Both organization } \\
\text { and language }\end{array}$ \\
\hline Arya & $\begin{array}{l}\text { I prefer comment on grammatical mistakes since when my } \\
\text { paper contains many grammatical errors, I cannot convey my } \\
\text { meaning so well. }\end{array}$ & Only language \\
\hline Saba & $\begin{array}{l}\text { In my opinion an accurate writing will be an understandable } \\
\text { one. So I would like to have comments on grammar. }\end{array}$ & Only language \\
\hline Rana & $\begin{array}{l}\text { I'd like the peer comments to indicate my erroneous sentences } \\
\text { since lacking accuracy in composition is a sign of low } \\
\text { proficiency in that language. }\end{array}$ & Critical comments \\
\hline Sanaz & $\begin{array}{l}\text { I like to receive comments that criticize my writing. I mean } \\
\text { the comments which only tell me the negative points of my } \\
\text { paper. }\end{array}$ & Critical comments \\
\hline
\end{tabular}


Responses to Q1 can be summarized as follows: a) the majority of students ( 9 students; $42.8 \%$ ) welcomed comment on organization; (b) five students (23.8\%) valued both content and organization comments; (c) four students (19.0\%) valued those peer comments which were about only language and mechanics and (d) three students $(14.2 \%)$ preferred to receive critical comments. Table 8 summarizes the excerpts of the students' responses to the second question of the interview ("would you like it if there were only peer comments but not teacher comments? Why?").

Table 8. Selected Interview Excerpts of Q2

\begin{tabular}{|l|l|l|}
\hline Student & \multicolumn{1}{|c|}{ Interview excerpts } & \multicolumn{1}{|c|}{$\begin{array}{c}\text { Main } \\
\text { theme }\end{array}$} \\
\hline Sam & $\begin{array}{l}\text { My peer comments were so useful and helped me a lot and also } \\
\text { the teacher comments provided me with sufficient information to } \\
\text { revise my writing. So both of them helped me. }\end{array}$ & $\begin{array}{l}\text { Both Peer } \\
\text { feedback } \\
\text { and teacher } \\
\text { feedback }\end{array}$ \\
\hline Sonia & $\begin{array}{l}\text { I need both of them. Because my peers helped me attend to my } \\
\text { ideas and make them relevant. The teacher could found all my } \\
\text { grammatical errors and made my writing accurate. }\end{array}$ & $\begin{array}{l}\text { Both Peer } \\
\text { feedback } \\
\text { and teacher } \\
\text { feedback }\end{array}$ \\
\hline Hoda & $\begin{array}{l}\text { I didn't like teacher comments; however, peer comments helped } \\
\text { me revise the details of my composition and correct my errors. }\end{array}$ & $\begin{array}{l}\text { Only peer } \\
\text { feedback }\end{array}$ \\
\hline Sahar & $\begin{array}{l}\text { The teacher marked just my grammatical mistakes. I'm aware that } \\
\text { my grammar is not that much good, but the teacher comments } \\
\text { negatively affected my confidence. So I don't like to receive } \\
\text { teacher comments anymore. }\end{array}$ & $\begin{array}{l}\text { Only peer } \\
\text { feedback }\end{array}$ \\
\hline Mohsen & $\begin{array}{l}\text { I preferred teacher comments. Peer comments helped me a little } \\
\text { since they just addressed surface errors; however, teacher } \\
\text { comments showed my organizational problems so beautifully and } \\
\text { completely }\end{array}$ & $\begin{array}{l}\text { Only } \\
\text { teacher } \\
\text { feedback }\end{array}$ \\
\hline Saba & $\begin{array}{l}\text { As my peers are the same level as me, I prefer to receive } \\
\text { comments from the teacher who is more proficient. }\end{array}$ & $\begin{array}{l}\text { Only } \\
\text { teacher } \\
\text { feedback }\end{array}$ \\
\hline
\end{tabular}

With respect to Q2, students' answers are as follows: (a) eleven interviewees (52.3\%) out of twenty-one, considered both peer and teacher feedback useful; (b) eight interviewees $(38.0 \%)$ out of twenty-one, investigated only peer feedback to be useful and (c) two interviewees $(9.5 \%)$ out of twenty-one considered only teacher feedback useful. Table 9 summarizes the excerpts of the students' responses to the third question of the interview ("Did you benefit from giving comments to others? If so, what were the benefits? If not, why not?"). 


\section{Table 9. Selected interview excerpts of Q3}

\begin{tabular}{|l|l|c|}
\hline \multicolumn{1}{|c|}{ Student } & \multicolumn{1}{|c|}{ Interview experts } & Main theme \\
\hline Samin & $\begin{array}{l}\text { Giving comments to others stimulated me to be more careful so } \\
\text { that I don't commit such errors in my own essay. Consequently, } \\
\text { my knowledge of grammar increased and the quality of my essays } \\
\text { becomes better. }\end{array}$ & It was useful \\
\hline Elif & $\begin{array}{l}\text { As a result of the process of giving comment, I learned how to give } \\
\text { comment. Because at first I was confused but gradually, I found so } \\
\text { many errors automatically and so easily. }\end{array}$ & It was useful \\
\hline sanaz & $\begin{array}{l}\text { Giving comments raised my confidence. Before this, I thought } \\
\text { only teachers can give comments and I, as a student, am not able to } \\
\text { do so. }\end{array}$ & It was useful \\
\hline Ali & $\begin{array}{l}\text { Reading and commenting on essays bring nothing new to me to } \\
\text { learn; I have already known everything. }\end{array}$ & It was useless \\
\hline Sasan & $\begin{array}{l}\text { I think giving comments needs proficiency and so only teachers } \\
\text { can give useful comments, so my friends' comments and mine are } \\
\text { not useful. }\end{array}$ & It was useless \\
\hline
\end{tabular}

Regarding Q3, (a) generally nineteen interviewees (90.4\%) claimed that giving feedback was useful and (b) only two of the interviewees $(9.5 \%)$ found giving feedback useless. Therefore, the majority of participants preferred to give feedback. Table 10 summarizes the excerpts of the students' responses to the fourth question ("Did you benefit from intra-feedback practice in your writing class? If so, what were the benefits? If not, why not?").

\section{Table 10. Selected interview excerpts of Q4}

\begin{tabular}{|l|l|l|}
\hline Student & Interview experts & Main theme \\
\hline Sahand & $\begin{array}{l}\text { While I was implementing the joint feedback of my reviewers, I was } \\
\text { almost certain about their accuracy because they spent time on } \\
\text { sharing and discussing their comments and checking uncertainties. }\end{array}$ & $\begin{array}{l}\text { It was useful } \\
\text { for writers }\end{array}$ \\
\hline Sanaz & $\begin{array}{l}\text { The joint comments of the two reviewers that I received were much } \\
\text { more than teacher comments. So I could correct so many of my } \\
\text { mistakes. }\end{array}$ & $\begin{array}{l}\text { It was useful } \\
\text { for writers }\end{array}$ \\
\hline Rima & $\begin{array}{l}\text { As a result of working with peers and discussing comments, I } \\
\text { learned to what aspects of essay I should focus. Before that time, I } \\
\text { attended to just grammar but now I understand that both grammar } \\
\text { and organization should be considered. }\end{array}$ & $\begin{array}{l}\text { It was useful } \\
\text { for reviewers }\end{array}$ \\
\hline Saba & $\begin{array}{l}\text { The process of intra-feedback helped me realize what elements are } \\
\text { important in writing. I paid attention to those points both for my later } \\
\text { writing and reviewing. }\end{array}$ & $\begin{array}{l}\text { It was useful } \\
\text { for reviewers }\end{array}$ \\
\hline Sina & $\begin{array}{l}\text { They gave several different comments to my paper and made me } \\
\text { confused. While editing, I didn't know which of their comments are } \\
\text { more accurate and more important for revision. }\end{array}$ & $\begin{array}{l}\text { It was useless } \\
\text { for writers }\end{array}$ \\
\hline Sana & $\begin{array}{l}\text { Discussing comments was so time-consuming and it tired me a lot. } \\
\text { It was useless } \\
\text { for reviewers }\end{array}$ \\
\hline
\end{tabular}


The responses of the participants to Q4 indicates that the majority of students (19 students; 90.4\%) perceived the intra-feedback practice beneficial in their writing class. Based on the responses to this item, it can be concluded that intra-feedback is useful not only for student writers but also for student reviewers. Table 11 summarizes the excerpts of the students' responses to the fifth question ("what types of teacher comments do you prefer?").

Table 11. Selected Interview Excerpts of Q5

\begin{tabular}{|c|c|c|}
\hline Student & Interview experts & Main theme \\
\hline Rana & $\begin{array}{l}\text { As I usually have grammatical and punctuation errors, I } \\
\text { appreciate comments referring to these mistakes. }\end{array}$ & $\begin{array}{l}\text { Only } \\
\text { organization }\end{array}$ \\
\hline Sanaz & $\begin{array}{l}\text { My friends didn't attend to the organization of my writing } \\
\text { and only the teacher comments helped to improve this } \\
\text { aspect. Thus, the teacher comments are necessary for } \\
\text { organizational improvement. }\end{array}$ & $\begin{array}{l}\text { Only } \\
\text { organization }\end{array}$ \\
\hline Ali & $\begin{array}{l}\text { I prefer to focus more on language and mechanics; } \\
\text { however, I am also aware of the importance of content and } \\
\text { organization. Since the reviewer or reader should also } \\
\text { comprehend what my message is. }\end{array}$ & $\begin{array}{l}\text { Both } \\
\text { organization } \\
\text { and } \\
\text { language }\end{array}$ \\
\hline Sana & $\begin{array}{l}\text { Both organizational and linguistic comments of the teacher } \\
\text { were helpful. He attended to both aspects almost equally. }\end{array}$ & $\begin{array}{l}\text { Both } \\
\text { organization } \\
\text { and } \\
\text { language }\end{array}$ \\
\hline Amir & $\begin{array}{l}\text { I prefer comment on grammatical mistakes since, when my } \\
\text { paper contains many grammatical errors I cannot convey } \\
\text { my meaning so well. }\end{array}$ & $\begin{array}{l}\text { Only } \\
\text { language }\end{array}$ \\
\hline Saba & $\begin{array}{l}\text { The grammatical corrections of my teacher were so useful. } \\
\text { His knowledge of grammar is so good that he could correct } \\
\text { almost all them. My revised draft became accurate enough. }\end{array}$ & $\begin{array}{l}\text { Only } \\
\text { language }\end{array}$ \\
\hline Roja & $\begin{array}{l}\text { I'd like those teacher comments that indicated my } \\
\text { erroneous sentences because lacking accuracy in } \\
\text { composition is indicator of low proficiency. }\end{array}$ & $\begin{array}{l}\text { Critical } \\
\text { comments }\end{array}$ \\
\hline Saman & $\begin{array}{l}\text { I don't like the comments that refer to strengths of my } \\
\text { writing because they don't lead to its improvement. But } \\
\text { critical comments, on any aspect, can make the writing } \\
\text { better. }\end{array}$ & $\begin{array}{l}\text { Critical } \\
\text { comments }\end{array}$ \\
\hline
\end{tabular}

With regard to Q5, all students perceived teacher's comments beneficial. Their responses can be summarized as follows: (a) the majority of the students (10students; 47.6\%) valued those teacher comments which concerned only organization; (b) five students (23.8\%) valued both grammatical and organizational comments; (c) four students (19.0\%) valued those teacher comments which 
concerned only language and mechanics and (d) only two participants $(9.5 \%)$ preferred to receive critical comments.

\section{Discussion}

Findings from the questionnaire data indicated that teacher feedback was more favorable than any other form of feedback. The finding of this study is in line with previous studies. For example, Leki (1991) surveyed college-level ESL composition students and reported that the participants judged their teachers as the most valuable source of feedback whereas fellow ESL students were reported to be the least beneficial. Zhang's (1995) investigation of eighty-one tertiary level ESL students with various levels of English language proficiency also showed that L2 respondents showed a very strong desire for teacher evaluations over other sources of help including peer feedback in their writing. Likewise, Hyde (1993), Nelson and Carson (1998), and Tsui and $\mathrm{Ng}$ (2000) separately investigated the attitudes of different cohorts of L2 learners and maintained that they did not perceive peer feedback as effective as teacher comments. They claimed that the learners attend to their teachers' advice more than their peers' suggestions. Amores (1997) also reported that her eight ESL undergraduate students viewed peer-editing activity counter-productive and they were defensive and reluctant of their papers being evaluated by their classmates. Finally, Yang and his colleagues (2006) reported that their Chinese EFL composition learners highly credited their teacher suggestions calling them more professional and valid compared to peer evaluation.

On the other hand, during the interview session, the majority of our students expressed their satisfaction for both teacher and peer feedback. Similarly, Mangelsdorf (1992) claimed that her forty heterogeneous advanced ESL composition participants studying at the University of Arizona assumed peer review technique beneficial as it could help student writers understand their audience expectations, view their texts from their perspectives, and clarify the misunderstandings if needed. Jacobs and his colleagues (1998) also argued that peer and teacher feedback were not mutually exclusive as their survey demonstrated that L2 students from Taiwan and Hong Kong welcomed them both. Finally, Roskams' (1999) and Saito and Fujita's (2004) separate investigations of 217 Chinese and 61 Japanese business students which were conducted at Hong Kong and Japan respectively indicated that even though their L2 respondents were more in favor of teacher comments, they also considered their partners' feedback useful and expressed favorable attitudes towards peer evaluation. Similar findings were obtained in our study, indicating that the participants are greatly in favor of 
developing error-free essays and became aware of their problematic areas during intra-feedback session.

\section{Conclusion}

Findings from the current study indicated that the students had a stronger desire to receive feedback from their teacher compared to other methods of feedback. The students also welcomed intra-feedback and peer comments since the mean scores were significantly high on all constructs; therefore, the findings can reassure EFL writing instructors that peer feedback can also be helpful for their students and that writing instructors should elucidate their rationale and integrate them into the composition courses with confidence. Using intra-feedback technique, teachers can create opportunities for students to improve their knowledge and become more aware of the criteria of effective reviewing; by implementation of this technique, students feel more confident in writing classrooms and can control their learning more than before since they discover their own competence as writers and reviewers. Learners' understanding of their roles in providing effective feedback may encourage them to actively participate in the task and appreciate the benefits of peer feedback. Hence, it is proposed that intra-feedback be used as a complementary activity to address some of the challenges associated with peer evaluation; namely, the validity of peer feedback and distrust in peer feedback.

It should be noted that this study had some methodological limitations which need to be considered. The first limitation is that the study was a classroom-based research with intact group; therefore, other variables such as sampling, gender, number of learners and their exposure to other classes may intervene in the effect of their preference. Another limitation of the study is that it has only considered one genre of writing, which is argumentative essay. Future research may therefore provide a wider view of this issue by considering the learning outcomes, the quality of students' comments as a result of teacher versus intra-feedback. 


\section{References and notes:}

Abadikhah, S. \& Yasami, F. (2014) Comparison of the effects of peer- versus self-editing on linguistic accuracy of Iranian EFL students. 3L: The Southeast Asian Journal of English Language Studies. 20(3), 113-124.

Allaei, S. K., \& Connor, U. M. (1990). Exploring the dynamics of cross-cultural collaboration in writing classrooms. The Writing Instructor, 10, 19-28.

Amores, M. J. (1997). A new perspective on peer-editing. Foreign Language Annals, 30(4), 513-522.

Azarnoosh, M. (2013). Peer assessment in an EFL context: Attitudes and friendship bias. Language Testing in Asia, 3(1).

Carson, J. G., \& Nelson, G. L. (1996). Chinese students' perceptions of ESL peer response group interaction. Journal of Second Language Writing, 5(1), 1-9.

Dörnyei, Z. \& Taguchi, T. (2010). Questionnaires in second language research: construction, administration, and processing: Second Language Acquisition Research Series. Hoboken: Taylor \& Francis.

Dörnyei, Z. (2003). Questionnaires in second language research. Mahwah, N.J.: Lawrence Erlbaum Associates.

Ferris, D. R. (2003). Response to student writing: implications for second language students. Mahwah NJ: Lawrence Erlbaum Associates.

Goldstein, L. M. (2004). Questions and answers about teacher written commentary and student revision: teachers and students working together. Journal of Second Language Writing, 13, 63-80.

Hong, F. (2006). Student' Perceptions of Peer Response Activity in English Writing. CELEA Journal, 29(4), 48-70.

Hu, G. (2005). Using peer review with Chinese ESL student writers. Language Teaching Research, 9(3), 321-342.

Hyde, M. (1993). Pair work - a blessing or a curse?: an analysis of pair work from pedagogical, cultural, social and psychological perspectives. System, 21(3), 343- 348.

Hyland, K., \& Hyland, F. (2006). Feedback on second language students' writing. Language Teaching, 39(2), 83-101.

Jacobs, H. L., Zingraf, S. A., Wormuth, D. R., Hartfiel, V. F., \& Hughey, J. B. (1981). Testing ESL composition: A practical approach. Rowley, MA: Newbury House.

Jacobs, G. M., Curtis, A., Braine, G., \& Huang, S.Y. (1998). Feedback on student writing: taking the middle path. Journal of Second Language Writing, 7(3), 307-317.

Jakeman, V. \& McDowell, C. (1996). Cambridge practice tests for IELTS 1. Cambridge: Cambridge University Press.

Kahraman, A., \& Yalvaç, F. (2015). EFL Turkish University Students' Preferences about Teacher Feedback and its Importance. Procedia-Social and Behavioral Sciences, 199, 73-80.

Kaufman, J. H., \& Schunn, C. D. (2011). Students' perceptions about peer assessment for writing: their origin and impact on revision work. Instructional Science, 39(3), 387409.

Keh, C. (1990). Feedback in the writing process: a model and methods for implementation. ELT Journal, 44(4), 294-304.

Lee, I., Mak, P., \& Burns, A. (2015). EFL teachers' attempts at feedback innovation in the writing classroom. Language Teaching Research, 20(2), 248-269.

Leki, I. (1991). The preferences of ESL students for error correction in college-level writing classes. Foreign Language Annals, 24(3), 203-218. 
Liu, J., \& Hansen, J. (2002). Peer response in second language writing classrooms. Ann Arbor: University of Michigan Press.

Mangelsdorf, K. (1992). Peer reviews in the ESL composition classroom: what do the students think? ELT Journal, 46, 274-284.

McGroarty, M. E., \& Zhu, W. (1997). Triangulation in classroom research: a study of peer revision. Language Learning, 47(1), 1-43.

Morra, A. M., \& Romano, M. E. (2009). University students' reactions to guided peer feedback and EAP compositions. Journal of College Literacy \& Learning, 35, 19- 30.

Nelson, G. L., \& Carson, J. G. (1998). ESL students' perceptions of effectiveness in peer response groups. Journal of Second Language Writing, 7(2), 113-131.

Nelson, G., \& Murphy, J. (1993). Peer response groups: Do L2 writers use peer comments in revising their drafts? TESOL Quarterly, 27(1), 135-142.

Reza Abbasian, Reza Biria (2017) English Language Textbooks in EFL Education:Do They Improve Students' National, International and Target Culture Familiarity?.Khazar Journal of Humanities and Social Sciences.Khazar University, Baku, Azerbaijan. Volume 20 № 2 2017,pp. 49-65

Rollinson, P. (2004). Thinking about Peer Review. Oxford: Oxford University Press.

Roskams, T. (1999). Chinese EFL students' attitudes to peer feedback and peer assessment in an extended pair work setting. RELC Journal, 30, 79-123.

Saito, H., \& Fujita, T. (2004). Characteristics and user acceptance of peer rating in EFL writing classrooms. Language Teaching Research, 8(1), 31-54.

Santos, T. (1992). Ideology in composition: L1 and ESL. Journal of Second Language Writing, 1(1), 1-15.

Tsui, A. B. M., \& Ng, M. (2000). Do secondary L2 writers benefit from peer comments? Journal of Second Language Writing, 9(2), 147-170.

Vygotsky, L.S.(1978). Mind in society: The development of higher mental processes. Cambridge: Harvard University Press.

Yang, M., Badger, R., \& Zhen, Y. (2006). A comparative study of peer and teacher feedback in Chinese EFL writing class. Journal of Second Language Writing, 15, 179200.

Zhang, S. (1995). Reexamining the affective advantage of peer feedback in the ESL writing class. Journal of Second Language Writing, 4(3), 209-222.

Zhang, S. (1999). Thoughts on some recent evidence concerning the affective advantage of peer feedback. Journal of Second Language Writing,8(3), 321-326. 


\title{
Summary
}

\section{EFL Students' Perceptions of Teacher Feedback and Intra- Feedback in Writing Essays}

\author{
Maryam Kazemi \\ University of Mazandaran, Iran \\ Shirin Abadikhah \\ University of Mazandaran, Iran \\ Mahmood Dehqan \\ University of Mazandaran, Iran
}

This study examines EFL students' perceptions of teacher feedback and intra-feedback in writing essays in an EFL university context. Traditionally, teachers who were considered more knowledgeable provided feedback to students' writing. Recently, peer feedback is considered as an alternative form of feedback, which involves a dynamic process of reviewing and discussing one another's text in a writing class. Intra-feedback, another form of peer feedback, is a reviewer-oriented practice in which two reviewers discuss their comments provided individually on the composition of another student. This paper investigates 21 EFL students' perceptions of teacher feedback and peer feedback using intra-feedback technique. Both quantitative and qualitative data were collected using a questionnaire and follow-up semi-structured interviews. The results of the questionnaire indicated that students perceived teacher feedback to be most useful in improving the content, organization and language of their essays. From the interviews with the students, their preferences toward feedback provider, feedback focus, feedback provision and intrafeedback inclusion were elicited. Some pedagogical implications for the EFL writing instruction can be made including creation of opportunities for students to become aware of effective reviewing techniques, improvement of peer feedback quality and increasing students' confidence and critical thinking.

Keywords: Written feedback; Intra-feedback; Teacher and Peer feedback; Students' perceptions 